\title{
TINGKAT KEBERHASILAN SAMBUNGAN DAN PERTUMBUHAN BIBIT KOPI ROBUSTA (COFFEA ROBUSTA L.) HASIL GRAFTING PADA PEMBERIAN BERBAGAI JENIS MIKORIZA DAN KETINGGIAN BATANG BAWAH
}

\author{
The Success of Grafting and Grafted Robusta Coffee (Coffea robusta L.) Seedlings Growth on \\ Mycorrhizae Application and Rootstock Height
}

\author{
Elis Kartika, Gusniwati \\ Universitas Jambi, Indonesia \\ Email: elisk63@yahoo.com
}

\begin{abstract}
Abstrak, Tujuan penelitian ini adalah untuk mendapatkan jenis mikoriza dan ketinggian batang bawah yang mampu meningkatkan keberhasilan sambungan sertapertumbuhan dan serapan $\mathrm{P}$ bibit kopi robustahasil grafting. Percobaan ini merupakan percobaan faktorial dua faktor menggunakan Rancangan Acak Lengkap tiga ulangan. Faktor pertama adalah inokulasi mikoriza yang terdiri dari enam taraf yaitu tanpa inokulasi mikoriza, inokulasiGlomus sp-3, Glomus sp-6, Glomus sp-15, Glomus $s p-16$, sertagabungan Glomus sp-3, sp-6, sp-15, sp-16. Faktor kedua berupa ketinggian batang bawah yang terdiri atas lima taraf yaitu ketinggian batang bawah 5, 10, 15, 20dan $25 \mathrm{~cm}$ dari pangkal akar.Hasil penelitianmenunjukkan bahwa pertumbuhan dan serapan P bibit kopi robusta hasil grafting terbaik pada berbagai jenis mikoriza diperoleh pada ketinggian batang bawah $15 \mathrm{~cm}$ dari pengkal akar. Pertumbuhan dan serapan P bibit kopi robusta hasil grafting pada berbagai ketinggian batang bawah diperoleh pada jenis mikoriza gabungan Glomus sp-3, sp-6, sp-15, sp-16. Tingkat keberhasilan penyambungan bibit kopi robusta bermikoriza adalah $100 \%$ dan bibit yang tidak bermikoriza sebesar $79.87 \%$, sedangkan pada berbagai ketinggian batang bawah berkisar anatar 95.83 sampai $97.22 \%$.
\end{abstract}

Abstract, The aim of this research was to obtain the mycorrhizae type and rootstockheight which was able to increase the grafting success, the growth and P uptake of grafted robusta coffee seedlings. This experiment is a two-factor factorial experiment using a completely randomized design of three replications. The first factor was mycorrhizal inoculation consisting of six levels, namely without mycorrhizal inoculation, inoculation of Glomus sp-3, Glomus sp-6, Glomus sp-15, Glomus sp-16, and mixed of Glomus sp-3, sp-6, sp-15, sp-16. The second factor is the rootstock height which consists of five levels, namely $5,10,15,20$ and $25 \mathrm{~cm}$ from base of the root. The results showed that the best growth and $\mathrm{P}$ uptake of grafted robusta coffee seedlings on various types of mycorrhizae were obtained at a $15 \mathrm{~cm}$ from the root baserootstock height. The growth and $\mathrm{P}$ uptake of grafted robusta coffee seedlings at rootstock heights obtained in the mixed ofGlomus sp-3, sp-6, sp-15, sp-16. The grafting success of the mycorrhizal grafted robusta coffee seedlings is $100 \%$ and the without mycorrhizal grafted robusta coffee seedlings are $79.87 \%$, while at various rootstock heights ranges from 95.83 to $97.22 \%$.

Keywords: Rootstock, Grafting, Mycorrhiza, Robusta Coffee.

\section{PENDAHULUAN}

Tanaman kopi (Coffea sp.) merupakansalah satu komoditas ekspor unggulan nasional. Tanaman ini merupakan salah satu hasil komoditi perkebunan yang memiliki nilai ekonomis yang cukup tinggi di antara tanaman perkebunan lainnya. Di Provinsi Jambi perkembangan tanaman kopi mengalami peningkatan dari tahun ke tahun. Luas areal dan produktivitas tanaman kopi di provinsi Jambi menempati urutan ke-13 di Indonesia. Pada tahun 2016, produktivitas kopi di Provinsi Jambi mencapai 0,515 ton/ha dengan luas areal panen 26.446 ha (Direktorat Jenderal Perkebunan, 2017).

Pengembangan tanaman kopi perlu terus mendapat perhatian dan ditingkatkan untuk menunjang peningkatan produksi kopi. Dalam pengembangannya kopi ini perlu ditunjang dengan penyediaan bibit yang unggul. Hal inilah yang menjadi faktor utama dalam menunjang keberhasilan pertanaman kopi di lapangan. Penggunaan bibit yang berkualitas baik dari pembibitan akan menghasilkan tanaman yang baik pula di lapangan. 
Kopi Robusta mempunyai sifat menyerbuk silang (cross pollination). Perbanyakan dengan biji menyebabkan turunannya tidak dapat mewarisi sifat-sifat unggul yang dimiliki oleh induknya dan penampilannya kurang seragam karena mengalami segregasi. Akibatnya hasil yang dicapai umumnya lebih rendah dari induknya (De Melo dan de Sousa, 2011). Upaya untuk mengatasi masalah tersebut di antaranya dapat dilakukan melalui penggunaan bibit unggul yang perbanyakannya secara grafting. Produktivitas tanaman kopi Robusta yang diperbanyak secara grafting dapat menghasilkan biji 1.108,4 kg/ha (Prawoto dan Yuliasmara, 2013), lebih tinggi $61,80 \%$ dari produktivitas kopi Robusta secara nasional.

Bibit kopi yang berkualitas dan kuantitas baik serta seragam dapat diperoleh melalui perbanyakan secara vegetatif. Sambung pucuk merupakan teknik perbanyakan vegetatif kopi yang paling sesuai. Perbanyakan dengan teknik sambung ini memiliki kelebihan antara lain hasil cepat diperoleh, pertumbuhan bibit memiliki vigor yang baik, dan serangan hama dan penyakit relatif rendah.

Pada perbanyakan secara grafting diperlukan bibit batang bawah yang memiliki pertumbuhan yang optimal sehingga mampu meningkatkan keberhasilan dan pertumbuhan bibit hasil grafting. Pertumbuhan bibit batang bawah yang subur dan sehat dapat diperoleh melalui pengoptimalan media pembibitan. Dalam rangka mengoptimalkan pertumbuhan dan perkembangan bibit batang bawah kopi tersebut, maka perlu aplikasi mikoriza yang merupakan salah satu alternatif strategi yang mungkin dapat dikembangkan. Untuk meningkatkan tingkat keberhasilan sambungan dan pertumbuhan bibit hasil grafting, selain memerlukan bibit batang bawah yang bagus, ketinggian batang bawah yang optimal juga sangat diperlukan.

Mikoriza dapat menguntungkan tanaman dalam hal penyediaan hara, antagonisme bagi organisme parasit akar, sinergisme dengan mikroba tanah lainnya, selain itu terlibat dalam siklus hara, perbaikan struktur tanah, alat transpor karbon dari akar tanaman bagi organisme tanah lainnya. Setiap jenis tanaman memberikan tanggap yang berbeda terhadap mikoriza, demikian juga dengan jenis tanah, berkaitan erat dengan $\mathrm{pH}$ dan tingkat kesuburan tanah. Setiap mikoriza mempunyai perbedaan dalam kemampuannya meningkatkan penyerapan hara dan pertumbuhan tanaman sehingga akan berbeda pula keefektivannya dalam meningkatkan pertumbuhan tanaman (Arman, 2009).

Telah banyak dibuktikan bahwa mikoriza mampu memperbaiki penyerapan hara khususnya fosfat (Bhattacharjee and Sharma, 2012; Kathlee. and Treseder, 2013; Watts-Williams Stephanie, et al.., 2014), meningkatkanketahanan tanaman terhadap cekaman abiotik (Wu and Zou, 2010; Ndiaye, et al., 2011; Zhu, et al., 2012), meningkatkan ketahanan tanaman terhadap cekaman logam berat (Krishnamoorthy, et al., 2015) dan meningkatkanketahanan tanaman terhadap cekaman biotik misalnyaserangan patogen akar (Sylvia dan Chellemi, 2001), dan pengendali penyakit busuk pangkal batang kelapa sawit (Simanjuntak, Fahridayanti dan Susanto, 2013).

Ketinggian batang bawah sangat menentukan keberhasilan sambungan dan pertumbuhan bibit hasil grafting selanjutnya. Hal ini berkaitan dengan kandungan cadangan makanan dan hormon yang menjadi faktor yang berpengaruh terhadap keberhasilan sambungan dan pertumbuhan bibit tersebut. Ketinggian batang bawah mempengaruhi pembentukan kalus dan penyatuan sambungan dari dalam yaitu melalui cadangan makanan, hormon dan protein pada batang dan kekuatan akar dari batang bawah. Menurut Harjadi dan Rochiman (1973, dalam Yusran dan Noer, 2011) bahwa kekuatan akar berpengaruh terhadap sambungan, dimana fungsi batang bawah pada umumnya pengabsorbsi air dan mineral.

Oleh karena itu kekuatan akar dari batang bawah akan mempengaruhi keaktifan pertumbuhan batang atas (entres). Tanaman yang mempunyai perakaran yang lebih kuat akan lebih dapat mendukung pertumbuhan entris. Hasil penelitian Fathan, Saptadi dan Ashari (2017) menunjukkan bahwa ketinggian batang yang lebih tinggi memberikan keberhasilan sambungan dan pertumbuhan tunas yang lebih tinggi.

Tujuan penelitian ini adalah untuk mendapatkan jenis mikoriza dan ketinggian batang bawah yang mampu meningkatkan keberhasilan sambungan sertapertumbuhan dan serapan $\mathrm{P}$ bibit kopi robustahasil grafting.

\section{METODE PENELITIAN}

Percobaan ini merupakan percobaan faktorial dua faktor menggunakan Rancangan 
Acak Lengkap tiga ulangan yaitu : faktor pertama adalah inokulasi mikoriza yang terdiri dari enam taraf yaitu tanpa inokulasi mikoriza, inokulasiGlomus sp-3, Glomus sp-6, Glomus sp-15, Glomus sp-16, sertagabungan Glomus sp-3, sp-6, sp-15, sp-16. Faktor kedua berupa ketinggian batang bawah yang terdiri atas 5 taraf yaitu ketinggian batang bawah 5, 10, 15, 20dan $25 \mathrm{~cm}$ dari pangkal akar.Dengan demikian, secara keseluruhan diperoleh 30kombinasi perlakuan. Setiap kombinasi perlakuan diulang tiga kali, sehingga terdapat 90 satuan percobaan. Setiap satuan percobaan terdiri dari 4polybag.

Batang bawah bibit kopi yang akan digrafting dalam penelitian ini berumur sekitar 6 bulan yang ditanam pada media tanah ultisol yang terlebih dahulu dikeringanginkan dan diayak dengan ayakan berukuran 10 mesh dan disterilisasi. Isolat mikoriza yang diberikan merupakan isolat mikoriza indigenous asal tambang batu bara yang diperoleh dari lahan bekas tambang batubara di Kabupaten Tebo (Kartika, et al., 2010) serta diberikan pada saat bibit kopi berumur 2 bulan.

Bibit kopi robusta yang sudah diinokulasi berbagai jenis mikoriza sesuai perlakuan selanjutnya dilakukan pemeliharaan yang meliputi penyiraman, pemupukan, pengendalian hama dan penyakit serta pengendalian gulma. Pupuk yang diberikan berupa pupuk urea, SP36, $\mathrm{KCl}$ dan kisserite yang diberikan setengah dosis dari anjuran. Pemupukan dilakukan dengan cara membuat alur di bagian pinggir polybag dan pupuk dibenamkan secara merata pada alur tersebut.

Batang atas (entres) diambil dari pohon induk yang ungggul. Entres sudah berumur 34 bulan dan memiliki lebih dari 5 ruas per batang. Adapun ruas yang dipakai sebagai batang atas hanya ruas kedua.Penyambungan dilakukan dengan metode celah, setelah disambung kemudian disungkup dengan kantong plastik transparan. Sungkup pastik dibuka setelah entris mengalami pecah tunas. Bibit kopi yang telah disambung tersebut ditempatkan di bawah naungan paranet $75 \%$ dan dipelihara secara optimal.

Pengamatan dilakukan terhadap peubah persentase bibit jadi, waktu tumbuh tunas, diameter tunas, panjang tunas, jumlah daun, bobot kering tunas, serapan $\mathrm{P}$ dan infeksi mikoriza. Pengamatan infeksimikoriza pada akar tanaman contoh dilakukan melalui teknik pewarnaan akar (staining akar) menggunakan metode dari Kormanik dan McGraw (1982).Untuk mengetahui pengaruh perlakuan terhadap variabel yang diamati, maka data hasil pengamatan dianalisis secara statistik dengan menggunakan sidik ragam dan uji lanjut Duncan pada taraf $\alpha=5 \%$.

\section{HASIL DAN PEMBAHASAN Hasil Penelitian}

\section{a. Panjang Tunas}

Nilai rata-rata panjang tunas kopi Robusta hasil grafting umur 4 bulan setelah penyambungan (BSP) pada perlakuan pemberian berbagai mikoriza dan ketinggian batang bawahdisajikan pada Tabel 1.Berdasarkan Tabel 1 terlihat bahwa pada perlakuan bebagai jenis mikoriza, panjang tunas tertinggi diperoleh pada ketinggian batang bawah $15 \mathrm{~cm}$ dari pangkal akar, sedangkan pada bibit yang tidak diberi mikoriza diperoleh pada ketinggian batang bawah $25 \mathrm{~cm}$.

Selanjutnya pada perlakuan berbagai ketinggian batang bawah, panjang tunas tertinggi diperoleh pada perlakuan jenis mikoriza gabungan Glomus sp-3,sp-6, sp15,sp-16.Pada ketinggian batang bawah $5 \mathrm{~cm}$, panjang tunas tertinggi selain dicapai pada jenis gabungan Glomus sp-3, sp-6, sp-15, sp-16juga diperoleh pada Glomus sp-16, untuk ketinggian $10 \mathrm{~cm}$ diperoleh juga pada Glomus sp-15, serta untuk ketinggian $15 \mathrm{~cm}$ diperoleh juga pada Glomus, sp-6, Glomus sp-15, dan Glomus sp16.

\section{b.Waktu Tumbuh Tunas}

Nilai rata-rata waktu tumbuh tunas bibit kopi Robusta hasil grafting umur 4 bulan setelah penyambungan(BSP) pada perlakuan pemberian berbagai mikoriza dan ketinggian batang bawahdisajikan pada Tabel 2. Pada perlakuan berbagai jenis mikoriza terlihat bahwa waktu tumbuh tunas tercepat dicapai pada perlakuan ketinggian batang bawah 15 $\mathrm{cm}$. dan yang terlama pada perlakuan ketinggian $5 \mathrm{~cm}$, sedangkan pada perlakuan tanpa mikoriza waktu tumbuh tunas tercepat pada ketinggian $25 \mathrm{~cm}$.

Selanjutnya pada berbagai ketinggian batang bawah, perlakuan tanpa mikoriza memperlihatkan waktu tumbuh tunas paling lama dibandingkan bibit yang bermikoriza dan yang tercepat umumnya pada perlakuan gabungan Glomus sp-3, sp-6, sp-15, sp-16 (Tabel 2). 


\section{c. Bobot Kering Tunas}

Nilai rata-rata bobot kering tunas bibit kopi Robusta hasil grafting umur 4 bulan setelah penyambungan(BSP) pada perlakuan pemberian berbagai mikoriza dan ketinggian batang bawahdisajikan pada Tabel 3 .

Tabel 3 memperlihatkan bahwa pada berbagai perlakuan mikoriza, bobot kering tunas tertinggi diperoleh pada ketinggian batang bawah $15 \mathrm{~cm}$, sedangkan pada bibit tanpa mikoriza diperoleh pada ketinggian batang bawah $25 \mathrm{~cm}$.

Selanjutnya pada berbagai ketinggian batang bawah, bobot kering tunas tertinggi dicapai pada bibit yang diberi mikoriza gabungan Glomus sp-3, sp-6, sp-15,sp-16. Pada ketinggian batang bawah $25 \mathrm{~cm}$, bobot kering tunas tertinggi juga diperoleh pada perlakuan tanpa mikoriza, selain pada gabungan Glomus sp-3, sp-6, sp-15, sp-16.

\section{d. Serapan $P$}

Nilai rata-rata serapan $\mathrm{P}$ bibit kopi Robusta hasil grafting umur 4 bulan setelah penyambungan(BSP) pada perlakuan pemberian berbagai mikoriza dan ketinggian batang bawahdisajikan pada Tabel 4 .

Tabel 4 memperlihatkan bahwa pada berbagai perlakuan mikoriza, serapan $\mathrm{P}$ tertinggi diperoleh pada ketinggian batang bawah $15 \mathrm{~cm}$, sedangkan pada bibit tanpa mikoriza diperoleh pada ketinggian batang bawah $25 \mathrm{~cm}$.

Selanjutnya pada perlakuan berbagai ketinggian batang bawah, serapan $\mathrm{P}$ tertinggi diperoleh pada perlakuan jenis mikoriza gabungan Glomus sp-3, sp-6, sp-15, sp-16.Pada ketinggian batang bawah $10 \mathrm{~cm}$, panjang tunas tertinggi selain dicapai pada jenis gabungan Glomus sp-3, sp-6, sp-15, sp-16juga diperoleh pada Glomus sp-6, untuk ketinggian $20 \mathrm{~cm}$ diperoleh juga pada Glomus sp-3, sedangkan padaa ketinggian batang bawah $25 \mathrm{~cm}$, serapan P tertinggi juga diperoleh pada perlakuan tanpa mikoriza.

\section{e. Diameter Tunas, Jumlah Daun, Bibit Jadi dan Infeksi Akar}

Berdasarkan hasil analisis tidak terjadi interaksi antara perlakuan jenis mikoriza dan ketinggian batang bawah untuk peubah diameter tunas, jumlah daun, bibit jadi dan infeksi akar. Nilai rata-rata diametertunas, jumlah daun, bibit jadi dan infeksi akar kopi Robusta hasil grafting umur 4 bulan setelah penyambungan (BSP) pada perlakuan pemberian berbagai mikoriza dan ketinggian batang bawahdisajikan pada Tabel 5 .

Berdasarkan Tabel 5 dapat dilihat bahwa bibit kopi robusta yang diberi mikoriza memiliki diameter tunas, jumlah daun, bibit jadi dan infeksi akar tertinggi dibandingkan dengan tanpa pemberian mikoriza. Jumlah daun tertinggi diperoleh pada bibit yang diberi mikoriza gabungan Glomus sp-3, sp-6, sp-15, sp-16. Selanjutnya ketinggian batang bawah yang memberikan diameter tunas dan jumlah daun tertinggi dicapai pada ketinggian $15 \mathrm{~cm}$ dari pangkal akar, sedangkan pada peubah bibit jadi dan infeksi akartidak menunjukkan perbedaan nyata.

Pembahasan

Hasil penelitian menunjukkan bahwa pada perlakuan bebagai jenis mikoriza, pertumbuhan dan serapan $P$ bibit hasil grafting tertinggi diperoleh pada ketinggian batang bawah $15 \mathrm{~cm}$ dari pangkal akar seperti ditunjukkan oleh peubah panjang tunas, bobot kering tunas dan serapan $\mathrm{P}$, sedangkan pada bibit tanpa mikoriza diperoleh pada ketinggian batang bawah $25 \mathrm{~cm}$ dari pangkal akar (Tabel 1, 3 dan 4).

Pada perbanyakan tanaman dengan penyambungan, peranan batang bawah dalam meningkatkan keberhasilan sambungan dan pertumbuhan bibit sangat besar. Pertumbuhan batang bawah yang optimal akan meningkatkan keberhasilan penyambungan dan pertumbuhan bibit sambungan. Mikoriza yang diberikan pada bibit kopi robusta sebagai batang bawah sudah mampu membantu meningkatkan pertumbuhan batang bawah sehingga bibit memiliki pertumbuhan yang baik, sehingga bibit yang disambung pada ketinggian $15 \mathrm{~cm}$ sudah mampu meningkatkan pertumbuhan bibit hasil grafting terbaik.

Menurut Soegito et al. (2002), peningkatan pertumbuhan disebabkan adanya percepatan pembelahan sel sebagai hasil proses fotosintesis dan proses fotosintesis akan berlangsung apabila proses transportasi hara dari tanah berlangsung baik. Pertautan sambungan yang baik akan mengantarkan hara yang diserap akar ke daun dan sebaliknya disalurkan ke seluruh bagian tanaman. Apabila proses metabolisme dalam tanaman terganggu yang disebabkan tidak baiknya jaringan tanaman, maka biosintesis hormon bekerja tidak optimal, akibatnya pertumbuhan dan perkembangan tanamanakan terhambat. Di 
samping itu, keberhasilan sambungan akan memacu transportasi hara dan air ke seluruh bagian tanaman batang atas yang akan mempengaruhi komponen pertumbuhan.

Prasad, et al. (2013) menunjukkan bahwa manfaat mikoriza pada tumbuhan terutama disebabkan oleh peningkatan penyerapan unsur hara, terutama fosfor. Peningkatan serapan ini disebabkan terjadi peningkatan luas permukaan kontak tanah, dan peningkatan pergerakan unsur hara ke hifa mikoriza, dan modifikasi lingkungan akar. Fosfor bergerak ke akar atau melalui difusi dan hifa mikoriza mengurangi jarak yang diperlukan untuk difusi sehingga meningkatkan penyerapan. Tingkat inflow fosfor ke mikoriza dapat mencapai enam kali lipat dari rambut akar. Selanjutnya diperoleh bukti bahwa mikoriza mampu meningkatkan pertumbuhan dan serapan $\mathrm{P}$ seperti hasil penelitian Habibzadeh (2015), İncesu, et al. (2015), Binu, et al. (2015), dan Hadianur, et al. (2016).

Ketinggian batang bawah berkaitan dengan kecukupan cadangan makanan/energi untuk pemulihan sel-sel yang rusak akibat pelukaan, makin panjang batang bawah diharapkan makin banyak pula cadangan energinya. Cadangan makanan yang cukup memadai, selain untuk proses pembentukan kalus sampai terbentuknya jaringan pembuluh juga untuk menunjang kelangsungan hidup sampai terjadinya aliran hara dari batang bawah. Menurut Lakitan (2001), di dalam batang terdapat zona pembelahan dan pembesaran sel yang aktif tumbuh sehingga apabila tersedia kandungan karbohidrat yang cukup dan seimbang akanmendorong pembelahan dan pembesaran sel pada batang terus meningkat. Salisbury and Ross (1995) menyatakan bahwa ada peran sitokinin indigen yang memacu pembelahan dan pembesaran sel. Sel yang semakin besar dan banyak akanmempengaruhi ukuran tunas. Menurut hasil penelitian Fathan, et al. (2017) perlakuan ketinggian batang bawah berpengaruh nyata terhadap panjang tunas dan jumlah daun, tetapi tidak nyata terhadap persentase keberhasilan top working, waktu tumbuh tunas dan diameter tunas durian.

Sementara itu, bibit kopi robusta hasil grafting yang tidak bermikoriza, pertumbuhan bibit tertinggi diperoleh pada ketinggian batang bawah $25 \mathrm{~cm}$. Hal ini terjadi karena tanpa mikoriza pertumbuhan batang bawah belum optimal sehingga untuk mendapatkan pertumbuhan yang baik harus diimbangi dengan ketinggian batang bawah yang akan disambung.

Bibit kopi tanpa mikoriza yang digrafting pada ketinggian batang bawah 5, 10, 15 dan $20 \mathrm{~cm}$ belum mampu meningkatkan pertumbuhan bibit kopi hasil grafting karena cadangan makanan yang ada kurang memadai. Hasil penelitian Barus (2000) menunjukkan bahwa tinggi batang bawah berpengaruh pada tinggi bibit. Batang bawah yang disambung pada tinggi $15 \mathrm{~cm}$ saat muncul daunnya lebih cepat daripada bibit yang disambung pada tinggi $10 \mathrm{~cm}$ dan $20 \mathrm{~cm}$.

Pada bibit kopi robusta bermikoriza hasil grafting memberikan pertumbuhan dan serapan $\mathrm{P}$ terbaik pada ketinggian $15 \mathrm{~cm}$. Hal ini diduga karena mikoriza mampu meningkatkan pertumbuhan, meningkatkan kemampuan tanaman dalam menyerap unsurunsur hara penting yang terdapat dalam tanah, seperti unsur $\mathrm{N}, \mathrm{P}, \mathrm{K}, \mathrm{Ca}, \mathrm{Cu}, \mathrm{Mn}$, dan $\mathrm{Mg}$, juga disebabkan karena akar tanaman dibantu oleh miselium jamur mikoriza eksternal dengan memperluas permukaan penyerapan akar, menghasikan zat pengatur tumbuh pada akar yang menyebabkan tanaman dapat tumbuh subur dan tidak mudah stress ketika mendapat perlakuan lingkungan yang berbeda, dan meningkatkan aerasi dalam tanah. Hal tersebut berhubungan dengan kemampuan mikoriza dalam memperbaiki agregat tanah, serta memacu perkembangan mikroba saprofit non patogenik disekitar perakaran sehingga tanaman dapat tumbuh dengan sehat dan subur.

Selanjutnya pada perlakuan berbagai ketinggian batang bawah, pertumbuhan dan serapan $\mathrm{P}$ bibit tertinggi diperoleh pada perlakuan jenis mikoriza gabungan Glomus sp3, sp-6, sp-15, sp-16, seperti ditunjukkan oleh peubah panjang tunas (Tabel 1), bobot kering tunas (Tabel 3), serapan P (Tabel 4). Gabungan Glomus sp-3, sp-6, sp-15, sp-16 ternyata memberikan pengaruh yang lebih baik, yang berarti keempat jenis mikoriza tersebut mampu bekerja sama secara sinergis dalam membantu meningkatkan pertumbuhan bibit hasil grafting. Seperti hasil penelitian Hadianur, et al. (2016) bahwa pertumbuhan dan serapan hara $\mathrm{N}$ yang terbaik diperoleh padagabungan mikoriza Glomus mosae + Gigaspora sp.

Pada ketinggian batang bawah $5 \mathrm{~cm}$, panjang tunas tertinggi selain dicapai pada jenis gabungan Glomus sp-3, sp-6, sp-15, sp-16juga diperoleh pada Glomus sp-16, untuk ketinggian 
$10 \mathrm{~cm}$ diperoleh juga pada Glomus sp-15, serta untuk ketinggian $15 \mathrm{~cm}$ diperoleh juga pada Glomus, sp-6 danGlomus sp-15. Hal ini menunjukkan bahwa setiap jenis mikoriza memiliki kemampuan untuk meningkatkan pertumbuhan dan serapan unsur hara.

Bibit kopi hasil grafting tanpa mikoriza memperlihatkan waktu tumbuh tunas paling lama dibandingkan bibit yang bermikoriza dan yang tercepat umumnya pada perlakuan gabungan Glomus sp-3, sp-6, sp-15, sp-16 (Tabel 2). Hal ini disebabkan bibit kopi robusta hasil grafting yang bermikoriza memiliki pertumbuhan yang lebh tinggi, sehingga memiliki cadangan makanan dan kandungan hormon yang lebih tinggi yang akan mempercepat munculnya tunas dibandingkan bibit kopi robusta yang tidak bermikoriza.

Bibit kopi robusta hasil grafting yang diberi mikoriza memiliki diameter tunas, jumlah daun, persentase bibit jadi, dan infeksi akar tertinggi dibandingkan dengan tanpa pemberian mikoriza (Tabel 4). Hal ini disebabkan mikoriza dapat meningkatkan penyerapan unsur hara, terutama P. Mikoriza ini dapat mengeluarkan enzim fosfatase dan asam-asam organik, khususnya oksalat yang dapat membantu membebaskan P. Mikoriza juga dapat membantu mengatasi masalah ketersediaan fosfat melalui dua cara, pengaruh langsung melalui jalinan hifa eksternal yang diproduksinya secara intensif sehingga tanaman bermikoriza akan mampu meningkatkan kapasitasnya dalam menyerap unsur hara dan air serta pengaruh tidak langsung, dimana mikoriza dapat memodifikasi fisiologis akar sehingga dapat mengeksresikan asam-asam organik dan fosfatase asam ke dalam tanah. Fosfatase asam merupakan suatu enzim yang dapat mamacu proses mineralisasi $\mathrm{P}$ organik dengan mengkatalisis pelepasan $\mathrm{P}$ dari kompleks organik menjadi kompleks anorganik. Seperti hasil penelitian Treseder (2013), Daras,et al. (2013), Fitrianto (2014), serta Mau dan Utami (2014).

Keberhasilan penyambungan dipengaruhi oleh kondisi batang bawah dan entres. Batang bawah yang berukuran besar (lebih panjang) mempunyai cadangan makanan lebih banyak, sedangkan cadangan makanan digunakan untuk pertumbuhan dan daya regenerasi tanaman. Hasil penelitian Barus (2000) tinggi batang bawah $15 \mathrm{~cm}$ menghasilkan pertumbuhan bibit jarak pagar asal sambungan lebih baik daripada tinggi batang bawah $10 \mathrm{~cm}$ dan $20 \mathrm{~cm}$. Panjang batang atas $7,5 \mathrm{~cm}$ dan $10 \mathrm{~cm}$ menghasilkan pertumbuhan bibit jarak pagar asal sambungan lebih baik daripada panjang batang atas $5 \mathrm{~cm}$.

Pada perlakuan berbagai ketinggian, persentase bibit jadi dan infeksi akar pada bibit kopi robusta hasil grafting tidak menunjukkan perbedaan yang nyata(Tabel 5). Hal ini disebabkan kandungan cadangan makanan dalam keadaan seimbang sehingga pembelahan, pembesaran dan diferensiasi sel juga berjalan dengan seimbang. Dalam kondisi seimbang ini,kandungan cadangan makanan yang terdapat pada masing-masing perlakuan ketinggian batang bawah sama-sama memadai untuk terjadinya penyambungan (Parsaulian dan Patriani, 2012).

Batang bawah yang memiliki cadangan makanan yang banyak akan membantu mempercepat terjadinya pertautan dengan batang atas. Keberhasilan pertautan dari bagian tanaman yang disambung ditentukan oleh kemampuan sel atau jaringan pada bagian yang dipertaut dalam membentuk sel-sel atau jaringan fungsional. Tirtawinata (2003) menjelaskan bahwa proses pertautan pada bagian tanaman yang disambung diawali oleh respons sel atau jaringan pada bagian yang terluka (bagian sambungan). Pelukaan (pengirisan) pada jaringan tanaman yang disambung menyebabkan sejumlah sel-sel parenchyma (pada entres dan batang bawah) rusak dan mati. Sel-sel yang rusak atau mati tersebut selanjutnya membentuk jaringan nekrotik. Jaringan nekrotik bertindak sebagai lapisan isolasi (isolation layer) dan merupakan reaksi jaringan tanaman untuk menghindari masuknya sumber kontaminan atau infeksi mikroorganisme. Sel-sel lain (sel hidup) yang terletak di bawah sel nekrotik akan mengalami hypertrophy yaitu pembelahan dan pembesaran sel hingga melewati ukuran normal dan disusul dengan hyperplasia atau pembelahan sel dalam jumlah banyak hingga membentuk kalus. Pertumbuhan sel-sel membentuk kalus sangat berperan dalam proses pertautan sambungan dan penyembuhan luka.

\section{KESIMPULAN}

Berdasarkan hasil dan pembahasan dapat ditarik kesimpulan sebagai berikut :

Pertumbuhan dan serapan P bibit kopi robusta hasil grafting terbaik pada berbagai jenis mikoriza diperoleh pada ketinggian batang bawah $15 \mathrm{~cm}$ dari pengkal akar. 
Pertumbuhan bibit kopi robusta hasil grafting pada berbagai ketinggian batang bawah diperoleh pada jenis mikoriza gabungan Glomus sp-3, sp-6, sp-15, sp-16.

Tingkat keberhasilan penyambungan bibit kopi robusta bermikoriza adalah $100 \%$ dan bibit yang tidak bermikoriza sebesar 79.87 $\%$, sedangkan pada berbagai ketinggian batang bawah berkisar anatar 95.83 sampai $97.22 \%$.

Infeksi akar pada bibit kopi robusta hasil grafting bermikoriza pada semua jenis mikoriza adalah $100 \%$ dan pada bibit yang tidak bermikoriza sebesar $3 \%$, sedangkan pada berbagai ketinggian batang bawah berkisar antara 83.75 sampai $83.80 \%$.

\section{UCAPAN TERIMA KASIH}

Terima kasih penulis ucapkan kepadaUniversitas Jambi melalui Penelitian dosen senior Nomor Kontrak: 2642/UN21.17/LT/2018 tanggal 17 Mei 2018, yang telah membiayai penelitian ini.

\section{DAFTAR PUSTAKA}

Arman. A., 2009. Uji efektivitas berbagai jenis tanaman inang terhadap perbanyakan spora mikoriza. http://armanarnat. blogspot.com/2009/10/uji-efektivitasberbagai-jenis-tanaman.html [17/5/2010].

Barus, T. 2000. Respon Fisiologi Jeruk Besar (Citrus grandis (L.) Kultivar "Cikoneng' dan 'Nambangan' terhadap Penyambungan dengan Beberapa Jenis Batang Bawah. (Tesis), Program Pascasarjana, Institut Pertanian Bogor.

Bhattacharjee, S., G.D. Sharma. 2012. Effect of dual inoculation of arbuscular mycorrhiza and rhizobium on the chlorophyll, nitrogen and phosphorus contents of pigeon pea (Cajanus cajan L.). Adv Microbiol 2: 561-564.

Binu, N.K., P.K. Ashokan \& M. Balasundaran.2015.Fungi and shade on growth of sandal (Santalum album) seedlings. Journal of Tropical Forest Science 27 (2) : 158-165.

Daras, U., O. Trisilawati dan I. Sobari. 2013. Pengaruh mikoriza dan ameliorant terhadap pertumbuhan benih kopi. Buletin RISTRI 4 (2) : 145-156.

De Melo, B. and L. B. de Sousa. 2011. Biology of reproduction Coffea arabica. L. and Coffea canephora Pierre. Revista Verde (Mossoró -RN-Brasil) 6 (2): 17.

Direktorat Jendral Perkebunan. 2017. Statistik Perkebunan Indonesia 2015-2017. Sekretariat Direktorat Jenderal, Direktorat Jenderal Perkebunan. Kementerian Pertanian

Fathan, N., D. Saptadi, dan S. Ashari. 2017. Pngaruh Ketinggian Batang Bawah Terhadap Keberhasilan Tumbuh Durian Kleting Kuning Dalam Sistem Top Working. Jurnal Produksi Tanaman 5 (3) : 404 - 409.

Fitrianto, Hermanto dan H. Kriswantoro. 2014. Studi pemanfaatan mikoriza arbuskular dan efisiensi pupuk phospat terhadap pertumbuhan dan produksi tanaman kacang hijau (Phaseolus radiates) pada tanah PMK.Prosiding Seminar Nasional Lahan Suboptimal 2014, Palembang 26-27

Habibzadeh, Y. The effect of arbuscular mycorrhizal fungi and phosphorus levels on dry matter production and root traits in cucumber (Cucumis sativus L.). African Journal of Environmental Sciences and Technology 9 (2) : 65-70.

Hadianur, Syafruddin, E. Kesumawati. 2016. Pengaruh jenis fungi mikoriza arbuscular terhadap pertumbuhan dan hasil tanaman tomat (Lycopersicum esculentum Mill). Jurnal Agrista 20 (3) : 126-134.

İncesu, M., T. Yeşiloğlu, B. Çimen, B. Yilmaz, Ç. Akpinar, İ. Ortaş.2015. Effects on growth of persimmon (Diospyros virginiana) rootstock of arbuscular mycorrhizal fungi species. Turk. J. Agric. For. 39: 117-122

Kartika, E., Lizawati dan Hamzah. 2010. Isolasi, karakterisasi dan pemurnian 
cendawan mikoriza arbuskular dari tanah bekas tambang batu bara. Prosiding Seminar Nasional MKTI. Jambi. 24-25 November 2010.

Kathleen, K. and Treseder. 2013. The extent of mycorrhizal colonization of roots and its influence on plant growth and phosphorus content . Plant Soil 371:113

Kormanik PP, Mc. Graw AC. 1982. Quantification of vesicular-arbuscular mycorrhizae in plant root. In $\mathrm{NC}$ Schenck. (ed.). Methods and Principles of Mycorrhizae Research. The American Phytop. Soc. 46 : 37-45

Krishnamoorthy, R., Chang-Gi Kim, P. Subramanian, Ki-Yoon Kim, G. Selvakumar, Tong-Min Sal. 2015. Arbuscular Mycorrhizal Fungi Community Structure, Abundance and Species Richness Changes in Soil by Different Levels of Heavy Metal and Metalloid Concentration PLOS ONE | DOI:10.1371/journal.pone.0128784

June 2, $2015: 1-15$

Lakitan, B. 2001. Fisiologi Pertum-buhan dan Perkembangan Tanaman. PT. RajaGrafindo Persada. Jakarta

Mau, A.E. and S.R. 2014. Utami Effects of biochar amendment and arbuscular mycorrhizal fungi inoculation on availability of soil phosphorus and growth of maize. Journal Of Degraded and Mining Lands Management 1 (2) : 69-74.

Ndiaye M, Cavalli E, Manga AGB, Diop TA (2011). Improved Acacia senegal growth after inoculation with arbuscular mycorrhizal fungi under water deficiency conditions. Int J Agric Biol 2: 271-274.

Parsaulian T, Putu D, B, dan Patriani. 2012. Pengaruh Panjang Entres terhadap Keberhasilan Sambung Pucuk Tanaman Jambu Air. Jurnal Sains Mahasiswa Pertanian. Vol. 1, No. 1: 19
Prasad, K.R.K., M. Singh and A. Kumar. 2013. Mycorrhiza Biofertilizer For Sustainable Agriculture. Agriways 1 (1) : 65-66.

Prawoto, A. A. and F. Yuliasmara. 2013. Effect of rootstocks on growth, yield and bean quality of Coffea canephora clones. Journal of Agricultural Science and Technology 3: 429-438.

Salisbury, F.B. dan C.W. Ross, 1995. Fisiologi Tumbuhan, Jilid 3. Penerbit ITB. Bandung.

Simanjuntak, D., Fahridayanti, dan A. Susanto. 2013. Efikasi mikoriza dan trichoderma sebagai pengendali Penyakit busuk pangkal batang (ganoderma) dan Sebagai pemacu pertumbuhan di pembibitan Kelapa sawit. Widyariset, Vol. 16 No. 2 : 233242.

Soegito, A. Soemargono dan Rebin. 2002. Kompatibilitas Antara Batang Bawah dan Batang Atas terhadap Pertumbuhan Mangga di Daerah Rendah Basah. Fakultas Pertanian Universitas Muhammad Yamin. J. Ilmu Pertanian Farming. 1(1):121-126.

Sylvia, D. M. and O.Chellemi. 2001, Interactions among root-inhabiting fungi and their implications for biological control of root pathogens. Advances in Agronomy. Volume 73 : $1-33$.

Tirtawinata, M. R., 2003. Kajian Anatomi dan Fisiologi Sambungan Bibit Manggis Dengan Beberapa Anggota Kerabat Clusiaceae. Disertasi. Program Pascasarjana Institut Pertanian Bogor

Treseder, K.K. 2013. The extent of mycorrhizal colonization of roots and its influence on plant growth and phosphorus content. Plant Soil 371:113.

Watts-Williams Stephanie J., Turney T. W., Patti A. F., Cavagnaro T. R., 2014 Uptake of zinc and phosphorus by plants is affected by zinc fertiliser 
material and arbuscular mycorrhizas, Plant Soil 376:165-175.

Wu, Q.S. and Y.N. Zou. 2010. Beneficial roles of arbuscular mycorrhizas in citrus seedlings at temperature stress. Sci Hort 125: 289-293.

Yusran, dan A,H. Noer, 2011. Keberhasilan Okulasi Varietas Jeruk Manis Pada
Berbagai Perbandingan Pupuk

Kandang. Media Litbang Sulteng. 4(2) : $97-104$

Zhu XC, Song FB, Liu SQ, Liu TD, Zhou X. 2012. Arbuscular mycorrhizae improves photosynthesis and water status of Zea mays L. under drought stress. Plant Soil Environ 58: 186-191.

Tabel 1 Rata-rata Panjang Tunas Kopi RobustaHasil Grafting umur 4BSP $(\mathrm{cm})$ pada Perlakuan Pemberian Mikoriza dan Ketinggian Batang Bawah

\begin{tabular}{|c|c|c|c|c|c|c|}
\hline \multirow{2}{*}{$\begin{array}{l}\text { Jenis } \\
\text { Mikoriza }\end{array}$} & \multicolumn{5}{|c|}{ Ketinggian Batang Bawah $(\mathrm{cm})$} & \multirow{2}{*}{ Rata-ratc } \\
\hline & 5 & 10 & 15 & 20 & 25 & \\
\hline $\begin{array}{l}\text { Tanpa } \\
\text { Mikoriza }\end{array}$ & $\begin{array}{l}11.00 \mathrm{~b} \\
\mathrm{~B}\end{array}$ & $\begin{array}{l}10.75 b \\
D\end{array}$ & $\begin{array}{l}9.00 \mathrm{~b} \\
\mathrm{C}\end{array}$ & $\begin{array}{l}9.58 b \\
D\end{array}$ & $\begin{array}{l}15.00 \mathrm{a} \\
\mathrm{AB}\end{array}$ & 11.07 \\
\hline Glomus sp-3 & $\begin{array}{l}10.75 d \\
B\end{array}$ & $\begin{array}{l}13.83 \mathrm{c} \\
\mathrm{C}\end{array}$ & $\begin{array}{l}17.00 \mathrm{a} \\
\mathrm{B}\end{array}$ & $\begin{array}{l}13.33 \mathrm{c} \\
\mathrm{C}\end{array}$ & $\begin{array}{l}14.17 \mathrm{~b} \\
\mathrm{~B}\end{array}$ & 13.82 \\
\hline Glomus sp-6 & $\begin{array}{l}9.00 \mathrm{~d} \\
B\end{array}$ & $\begin{array}{l}17.25 b \\
B\end{array}$ & $\begin{array}{l}26.50 \mathrm{a} \\
\mathrm{A}\end{array}$ & $\begin{array}{l}14.58 \mathrm{c} \\
\mathrm{B}\end{array}$ & $\begin{array}{l}14.75 \mathrm{c} \\
\mathrm{AB}\end{array}$ & 16.42 \\
\hline $\begin{array}{l}\text { Glomus sp- } \\
15\end{array}$ & $\begin{array}{l}9.58 \mathrm{~b} \\
\mathrm{~B} \\
\end{array}$ & $\begin{array}{l}20.17 b \\
\text { A }\end{array}$ & $\begin{array}{l}26.50 \mathrm{a} \\
\mathrm{A}\end{array}$ & $\begin{array}{l}16.33 \mathrm{c} \\
\mathrm{B}\end{array}$ & $\begin{array}{l}12.00 \mathrm{~d} \\
\mathrm{C}\end{array}$ & 16.92 \\
\hline $\begin{array}{l}\text { Glomus sp- } \\
16\end{array}$ & $\begin{array}{l}15.00 \mathrm{bc} \\
\mathrm{A}\end{array}$ & $\begin{array}{l}14.58 \mathrm{c} \\
\mathrm{C}\end{array}$ & $\begin{array}{l}25.67 \mathrm{a} \\
\mathrm{A}\end{array}$ & $\begin{array}{l}17.00 \mathrm{~b} \\
\mathrm{AB}\end{array}$ & $\begin{array}{l}15.33 b c \\
A B\end{array}$ & 17.52 \\
\hline $\begin{array}{l}\text { Glomus } s p-3, \\
s p-6, \quad s p-15 \\
\text { dan } s p-16 .\end{array}$ & $\begin{array}{l}16.00 \mathrm{~d} \\
\text { A }\end{array}$ & $\begin{array}{l}21.83 \mathrm{~b} \\
\mathrm{~A}\end{array}$ & $\begin{array}{l}27.83 \mathrm{a} \\
\mathrm{A}\end{array}$ & $\begin{array}{l}18.83 \mathrm{c} \\
\mathrm{A}\end{array}$ & $\begin{array}{l}17.33 \mathrm{~cd} \\
\mathrm{~A}\end{array}$ & 20.37 \\
\hline Rata-rata & 11.89 & 16.40 & 22.08 & 14.94 & 14.76 & \\
\hline
\end{tabular}

Tabel 2 Rata-rata Waktu Tumbuh Tunas Bibit Kopi RobustaHasil Grafting umur 4BSP (hari) pada Perlakuan Pemberian Mikoriza dan Ketinggian Batang Bawah

\begin{tabular}{|c|c|c|c|c|c|c|}
\hline \multirow{2}{*}{$\begin{array}{l}\text { Jenis } \\
\text { Mikoriza }\end{array}$} & \multicolumn{5}{|c|}{ Ketinggian Batang Bawah (cm) } & \multirow{2}{*}{ Rata-rata } \\
\hline & 5 & 10 & 15 & 20 & 25 & \\
\hline Tanpa & $29.00 \mathrm{a}$ & $26.50 \mathrm{~b}$ & $24.33 b$ & $24.33 b$ & $22.50 \mathrm{c}$ & 25.33 \\
\hline Mikoriza & A & A & A & A & $\mathrm{C}$ & \\
\hline Glomus sp-3 & $\begin{array}{l}26.50 a \\
B\end{array}$ & $\begin{array}{l}20.83 c \\
D E\end{array}$ & $\begin{array}{l}20.00 \mathrm{e} \\
B C\end{array}$ & $\begin{array}{l}20.17 d \\
C\end{array}$ & $\begin{array}{l}23.83 b \\
\text { B }\end{array}$ & 22.27 \\
\hline Glomus sp-6 & $\begin{array}{l}24.33 a \\
C \\
\end{array}$ & $\begin{array}{l}21.17 b \\
C D\end{array}$ & $\begin{array}{l}20.50 \mathrm{c} \\
\mathrm{B} \\
\end{array}$ & $\begin{array}{l}20.83 b c \\
B\end{array}$ & $\begin{array}{l}24.33 \mathrm{a} \\
\mathrm{A}\end{array}$ & 22.23 \\
\hline $\begin{array}{l}\text { Glomus sp- } \\
15\end{array}$ & $\begin{array}{l}24.33 \mathrm{a} \\
\mathrm{C}\end{array}$ & $\begin{array}{l}23.50 \mathrm{~b} \\
\mathrm{AB}\end{array}$ & $\begin{array}{l}20.17 \mathrm{c} \\
\mathrm{BC}\end{array}$ & $\begin{array}{l}20.17 \mathrm{c} \\
\mathrm{C}\end{array}$ & $\begin{array}{l}23.33 b \\
C\end{array}$ & 22.30 \\
\hline
\end{tabular}


Kartika, Gusniwati TINGKAT KEBERHASILAN SAMBUNGAN DAN PERTUMBUHAN BIBIT KOPI ROBUSTA (COFFEA ROBUSTA L.) HASIL GRAFTING PADA PEMBERIAN BERBAGAI JENIS

\begin{tabular}{|c|c|c|c|c|c|c|}
\hline $\begin{array}{l}\text { Glomus sp- } \\
16\end{array}$ & $\begin{array}{l}22.50 \mathrm{~b} \\
\mathrm{D}\end{array}$ & $\begin{array}{l}22.83 \mathrm{a} \\
\mathrm{BC}\end{array}$ & $\begin{array}{l}20.00 \mathrm{c} \\
\mathrm{C}\end{array}$ & $\begin{array}{l}20.17 \mathrm{c} \\
\mathrm{C}\end{array}$ & $\begin{array}{l}22.67 \mathrm{~b} \\
\mathrm{C}\end{array}$ & 21.63 \\
\hline $\begin{array}{l}\text { Glomus sp-3, } \\
\text { sp-6, sp-15, } \\
\text { dan } s p-16 .\end{array}$ & $\begin{array}{l}21.50 \mathrm{a} \\
\mathrm{D}\end{array}$ & $\begin{array}{l}20.33 b \\
E\end{array}$ & $\begin{array}{l}19.00 \mathrm{c} \\
\mathrm{C}\end{array}$ & $\begin{array}{l}19.50 \mathrm{c} \\
\mathrm{D}\end{array}$ & $\begin{array}{l}21.83 \mathrm{a} \\
\mathrm{D}\end{array}$ & 20.43 \\
\hline Rata-rata & 24.69 & 22.53 & 20.67 & 20.86 & 23.08 & \\
\hline
\end{tabular}

Keterangan :- Angka yang diikuti huruf besar menurut kolom dan huruf kecil menurut baris yang sama tidak berbeda nyata pada taraf5 \% uji DMNRT

- BSP = Bulan Setelah Penyambungan

Tabel 3 Rata-rata Bobot Kering Tunas Bibit Kopi RobustaHasil Grafting umur 4BSP (g) pada Perlakuan Pemberian Mikoriza dan Ketinggian Batang Bawah

\begin{tabular}{|c|c|c|c|c|c|c|}
\hline \multirow{2}{*}{$\begin{array}{l}\text { Jenis } \\
\text { Mikoriza }\end{array}$} & \multicolumn{5}{|c|}{ Ketinggian Batang Bawah $(\mathrm{cm})$} & \multirow{2}{*}{ Rata-ratc } \\
\hline & 5 & 10 & 15 & 20 & 25 & \\
\hline Tanpa & $2.29 b$ & $2.37 \mathrm{~b}$ & $2.23 b$ & $2.36 \mathrm{~b}$ & $3.36 \mathrm{a}$ & 2.52 \\
\hline Mikoriza & $\mathrm{BC}$ & $\mathrm{C}$ & $\mathrm{D}$ & $\mathrm{D}$ & $\mathrm{A}$ & \\
\hline Glomus sp-3 & $\begin{array}{l}1.60 \mathrm{~d} \\
\mathrm{E}\end{array}$ & $\begin{array}{l}2.82 \mathrm{c} \\
\mathrm{B}\end{array}$ & $\begin{array}{l}3.48 \mathrm{a} \\
\mathrm{B}\end{array}$ & $\begin{array}{l}3.21 \mathrm{~b} \\
\mathrm{~B}\end{array}$ & $\begin{array}{l}3.07 b \\
\text { B }\end{array}$ & 2.84 \\
\hline Glomus sp-6 & $\begin{array}{l}2.12 \mathrm{c} \\
\mathrm{CD}\end{array}$ & $\begin{array}{l}2.12 \mathrm{c} \\
\mathrm{D}\end{array}$ & $\begin{array}{l}3.50 \mathrm{a} \\
\mathrm{B} \\
\end{array}$ & $\begin{array}{l}3.14 \mathrm{~b} \\
\mathrm{~B}\end{array}$ & $\begin{array}{l}1.78 \mathrm{~d} \\
\mathrm{D}\end{array}$ & 2.53 \\
\hline $\begin{array}{l}\text { Glomus sp- } \\
15\end{array}$ & $\begin{array}{l}2.42 d \\
B\end{array}$ & $\begin{array}{l}3.01 \mathrm{~b} \\
\mathrm{~B}\end{array}$ & $\begin{array}{l}3.56 \mathrm{a} \\
\mathrm{B}\end{array}$ & $\begin{array}{l}2.64 \mathrm{c} \\
\mathrm{C}\end{array}$ & $\begin{array}{l}2.82 \mathrm{c} \\
\mathrm{C}\end{array}$ & 2.89 \\
\hline $\begin{array}{l}\text { Glomus sp- } \\
16\end{array}$ & $\begin{array}{l}2.07 \mathrm{c} \\
\mathrm{D}\end{array}$ & $\begin{array}{l}2.85 \mathrm{ab} \\
\mathrm{B}\end{array}$ & $\begin{array}{l}3.02 \mathrm{a} \\
\mathrm{C}\end{array}$ & $\begin{array}{l}2.77 b \\
C\end{array}$ & $\begin{array}{l}2.77 b \\
C\end{array}$ & 2.68 \\
\hline $\begin{array}{l}\text { Glomus } s p-3 \text {, } \\
\text { sp-6, sp-15, } \\
\text { dan } s p-16 .\end{array}$ & $\begin{array}{l}3.43 \mathrm{~b} \\
\mathrm{~A}\end{array}$ & $\begin{array}{l}3.46 \mathrm{~b} \\
\mathrm{~A}\end{array}$ & $\begin{array}{l}3.91 \mathrm{a} \\
\mathrm{A}\end{array}$ & $\begin{array}{l}3.44 \mathrm{~b} \\
\mathrm{~A}\end{array}$ & $\begin{array}{l}3.39 \mathrm{~b} \\
\mathrm{~A}\end{array}$ & 3.53 \\
\hline Rata-rata & 2.32 & 2.77 & 3.28 & 2.93 & 2.86 & \\
\hline
\end{tabular}

Keterangan :- Angka yang diikuti huruf besar menurut kolom dan huruf kecil menurut baris yang sama tidak berbeda nyata pada taraf5 \% uji DMNRT

- BSP = Bulan Setelah Penyambungan

Tabel 4 Rata-rata Serapan P Bibit Kopi RobustaHasil Grafting umur 4BSP (g/bibit) pada Perlakuan Pemberian Mikoriza dan Ketinggian Batang Bawah

\begin{tabular}{|c|c|c|c|c|c|c|}
\hline \multirow{2}{*}{$\begin{array}{l}\text { Jenis } \\
\text { Mikoriza }\end{array}$} & \multicolumn{5}{|c|}{ Ketinggian Batang Bawah $(\mathrm{cm})$} & \multirow{2}{*}{ Rata-rata } \\
\hline & 5 & 10 & 15 & 20 & 25 & \\
\hline Tanpa & $0.465 \mathrm{e}$ & $0.518 \mathrm{~d}$ & $0.566 \mathrm{c}$ & $0.615 b$ & $1.054 \mathrm{a}$ & 0.644 \\
\hline Mikoriza & $\mathrm{C}$ & $\mathrm{C}$ & E & $\mathrm{D}$ & A & \\
\hline Glomus sp-3 & $\begin{array}{l}0.350 \mathrm{e} \\
\mathrm{D}\end{array}$ & $\begin{array}{l}0.639 d \\
B\end{array}$ & $\begin{array}{l}1.13 \mathrm{a} \\
\mathrm{C}\end{array}$ & $\begin{array}{l}0.862 b \\
A\end{array}$ & $\begin{array}{l}0.827 \mathrm{c} \\
\mathrm{B}\end{array}$ & 0.763 \\
\hline Glomus sp-6 & $\begin{array}{l}0.478 \mathrm{~d} \\
\mathrm{C}\end{array}$ & $\begin{array}{l}0.617 \mathrm{c} \\
\mathrm{A}\end{array}$ & $\begin{array}{l}1.253 \mathrm{a} \\
\mathrm{B}\end{array}$ & $\begin{array}{l}0.793 b \\
B\end{array}$ & $\begin{array}{l}0.415 \mathrm{e} \\
\mathrm{E}\end{array}$ & 0.711 \\
\hline $\begin{array}{l}\text { Glomus sp- } \\
15\end{array}$ & $\begin{array}{l}0.634 \mathrm{c} \\
\mathrm{B}\end{array}$ & $\begin{array}{l}0.871 \mathrm{~b} \\
\mathrm{~B}\end{array}$ & $\begin{array}{l}1.239 \mathrm{a} \\
\mathrm{B}\end{array}$ & $\begin{array}{l}0.654 \mathrm{c} \\
\mathrm{D}\end{array}$ & $\begin{array}{l}0.621 \mathrm{c} \\
\mathrm{D}\end{array}$ & 0.804 \\
\hline $\begin{array}{l}\text { Glomus sp- } \\
16\end{array}$ & $\begin{array}{l}0.460 \mathrm{~d} \\
C\end{array}$ & $\begin{array}{l}0.655 \mathrm{c} \\
\mathrm{B}\end{array}$ & $\begin{array}{l}1.006 \mathrm{a} \\
\mathrm{D}\end{array}$ & $\begin{array}{l}0.734 b \\
C\end{array}$ & $\begin{array}{l}0.700 \mathrm{~b} \\
\mathrm{C}\end{array}$ & 0.714 \\
\hline
\end{tabular}


Biospecies Vol. 12 No. 2, Juli 2019. Hal 9 - 19

\begin{tabular}{|c|c|c|c|c|c|c|}
\hline $\begin{array}{l}\text { Glomus sp-3, } \\
\text { sp-6, sp-15, } \\
\text { dan sp-16. }\end{array}$ & $\begin{array}{l}0.803 \mathrm{c} \\
\mathrm{A}\end{array}$ & $\begin{array}{l}0.862 \mathrm{~b} \\
\mathrm{~A}\end{array}$ & $\begin{array}{l}1.642 \mathrm{a} \\
\mathrm{A}\end{array}$ & $\begin{array}{l}0.842 \mathrm{~b} \\
\mathrm{~A}\end{array}$ & $\begin{array}{l}0.800 \mathrm{c} \\
\mathrm{B}\end{array}$ & 0.990 \\
\hline Rata-rata & 0.532 & 0.694 & 1.140 & 0.750 & 0.736 & 0.771 \\
\hline
\end{tabular}

Tabel 5 Rata-rata DiameterTunasBatang Atas, Jumlah Daun, Bibit Jadi dan Infeksi Akar Kopi RobustaHasil Grafting umur 4BSP pada Perlakuan Pemberian Mikoriza dan Ketinggian Batang Bawah

\begin{tabular}{|c|c|c|c|c|c|}
\hline Jenis Mikoriza & $\begin{array}{l}\text { Diameter } \\
\text { Tunas (mm) }\end{array}$ & $\begin{array}{l}\text { Jumlah } \\
\text { Daun (helai) }\end{array}$ & $\begin{array}{l}\text { Bibit Jadi } \\
(\%)\end{array}$ & $\begin{array}{l}\text { Infeksi } \\
(\%)\end{array}$ & Akar \\
\hline Tanpa Mikoriza & $2.37 \mathrm{~b}$ & $6.00 \mathrm{c}$ & $79.17 \mathrm{~b}$ & $3.00 \mathrm{~b}$ & \\
\hline Glomus sp-3 & $2.82 \mathrm{a}$ & $7.73 b$ & $100.00 \mathrm{a}$ & $100.00 \mathrm{a}$ & \\
\hline Glomus sp-6 & $3.00 \mathrm{a}$ & $7.93 b$ & $100.00 \mathrm{a}$ & $100.00 \mathrm{a}$ & \\
\hline Glomus sp-15 & $2.73 \mathrm{a}$ & $8.40 \mathrm{~b}$ & $100.00 \mathrm{a}$ & $100.00 \mathrm{a}$ & \\
\hline Glomus sp-16 & $2.73 \mathrm{a}$ & $7.60 \mathrm{~b}$ & $100.00 \mathrm{a}$ & $100.00 \mathrm{a}$ & \\
\hline Glomus sp-3, sp-6, sp-15, dan sp- & $2.84 \mathrm{a}$ & & & & \\
\hline & & $10.20 \mathrm{a}$ & $100.00 \mathrm{a}$ & $100.00 \mathrm{a}$ & \\
\hline \multicolumn{6}{|l|}{ Ketinggian batang bawah $(\mathrm{cm})$} \\
\hline 5 & $2.57 \mathrm{c}$ & $5.89 \mathrm{~d}$ & $95.83 \mathrm{a}$ & $83.89 \mathrm{a}$ & \\
\hline 10 & $2.60 b c$ & $7.17 \mathrm{c}$ & $96.53 \mathrm{a}$ & $83.75 \mathrm{a}$ & \\
\hline 15 & $3.23 \mathrm{a}$ & $10.28 \mathrm{a}$ & $95.83 \mathrm{a}$ & $83.89 \mathrm{a}$ & \\
\hline 20 & $2.67 b c$ & $8.78 \mathrm{~b}$ & $97.22 \mathrm{a}$ & $83.75 \mathrm{a}$ & \\
\hline 25 & $2.68 b$ & $7.78 \mathrm{bc}$ & $97.22 \mathrm{a}$ & $83.89 \mathrm{a}$ & \\
\hline
\end{tabular}

Keterangan :- Angka yang diikuti huruf kecil yang sama tidak berbeda nyata pada taraf5 \% uji DMNRT - BSP = Bulan Setelah Penyambungan 